\title{
Summary Report: Legacy Education, Public Awareness, and Recreation Task Area
}

by Paul R. Nickens, Michael R. Waring Environmental Laboratory

Walter H. Bumgardner University of Southern Mississippi 
The contents of this report are not to be used for advertising, publication, or promotional purposes. Citation of trade names does not constitute an official endorsement or approval of the use of such commercial products.

\section{PRINTED ON RECYCLED PAPER}




\section{8}

\section{Legacy Resource}

Management Program
TAT

W 34

$n 0 . E L-93-16$

$\mathrm{C} \cdot \mathrm{m}^{2}$

Technical Report EL-93-16

August 1993

\section{Summary Report: \\ Legacy Education, Public Awareness, and Recreation Task Area}

by Paul R. Nickens, Michael R. Waring

Environmental Laboratory

U.S. Army Corps of Engineers

Waterways Experiment Station

3909 Halls Ferry Road

Vicksburg, MS 39180-6199

Walter $\mathrm{H}$. Bumgardner

School of Human Performance and Recreation

University of Southern Mississippi

Hattiesburg, MS 39405-5142

Final report

Approved for public release; distribution is unlimited

Prepared for U.S. Department of Defense

Office of the Deputy Assistant Secretary of Defense for the Environment

Washington, DC 22202 


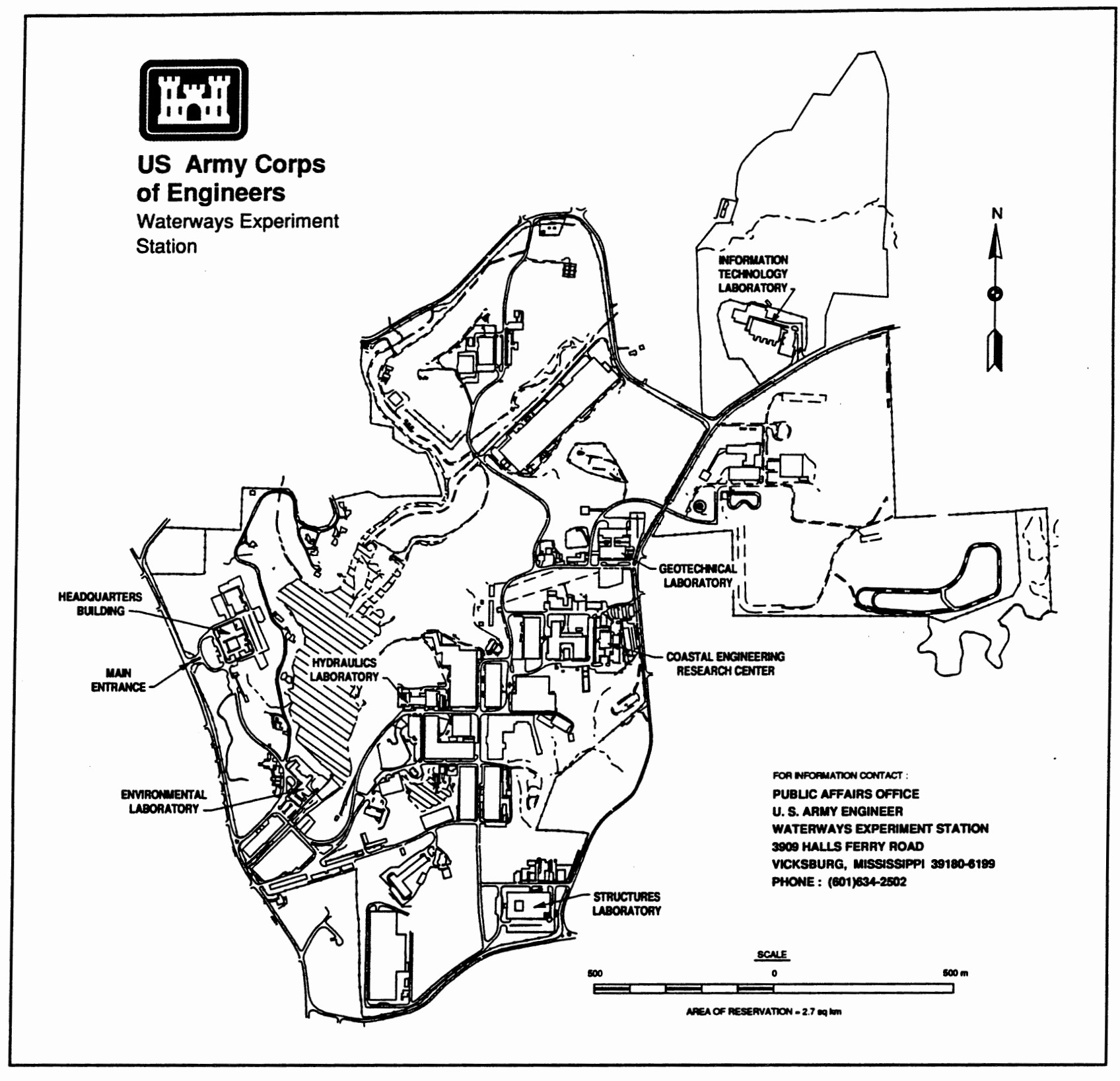

Waterways Experiment Station Cataloging-in-Publication Data

Nickens, Paul R.

Summary report: Legacy Education, Public Awareness, and Recreation Task Area / by Paul R. Nickens, Michael R. Waring, Walter H. Bumgardner ; prepared for U.S. Department of Defense, Office of the Deputy Assistant Secretary of Defense for the Environment.

32 p. : ill. ; $28 \mathrm{~cm}$. - (Technical report ; EL-93-16) Includes bibliographical references.

1. Cultural property, Protection of - United States. 2. Natural areas United States. 3. Public lands - United States. I. Waring, Michael R. II. Bumgardner, Walter H. III. United States. Office of the Deputy Assistant Secretary of Defense (Environment). IV. U.S. Army Engineer Waterways Experiment Station. V. Legacy Resource Management Program. VI. Title. VII. Title: Legacy education, public awareness, and recreation task area. VIII. Series: Technical report (U.S. Army Engineer Waterways Experiment Station) ; EL-93-16.

TA7 W34 no.EL-93-16 


\section{Contents}

Preface $\ldots \ldots \ldots \ldots \ldots \ldots \ldots \ldots \ldots \ldots \ldots \ldots \ldots, v$

1 -Introduction $\ldots \ldots \ldots \ldots \ldots \ldots \ldots \ldots \ldots \ldots \ldots \ldots$

Background ........................... 1

Purpose and Organization of the Report $\ldots \ldots \ldots \ldots \ldots \ldots \ldots 2$

2-Task Area Framework $\ldots \ldots \ldots \ldots \ldots \ldots \ldots \ldots \ldots \ldots \ldots$

Management and Personnel $\ldots \ldots \ldots \ldots \ldots \ldots \ldots \ldots \ldots$

Subtask Area Objectives $\ldots \ldots \ldots \ldots \ldots \ldots \ldots \ldots \ldots \ldots$

Natural resources objectives ................... 3

Cultural resources objectives $\ldots \ldots \ldots \ldots \ldots \ldots \ldots \ldots 4$

Procedures and Methods $\ldots \ldots \ldots \ldots \ldots \ldots \ldots \ldots \ldots$

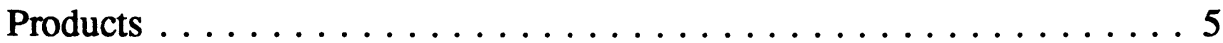

$3-$ Conclusions and Recommendations $\ldots \ldots \ldots \ldots \ldots \ldots 6$

Natural Resources - Conclusions $\ldots \ldots \ldots \ldots \ldots \ldots \ldots \ldots 6$

Authority and access $\ldots \ldots \ldots \ldots \ldots \ldots \ldots \ldots \ldots \ldots \ldots \ldots \ldots$

Resources and activities $\ldots \ldots \ldots \ldots \ldots \ldots \ldots \ldots \ldots \ldots$

Mandated access . . . . . . . . . . . . . . . . 8

Native American access . ................... 8

Public awareness, public relations, education, and user

information $\ldots \ldots \ldots \ldots \ldots \ldots \ldots \ldots \ldots, \ldots$

Legal liabilities $\ldots \ldots \ldots \ldots \ldots \ldots \ldots \ldots \ldots \ldots$

Conceptual frameworks .................... 10

Non-DoD Federal management policies . . . . . . . . . . . 10

Natural Resources - Recommendations ............... 11

Authority and access $\ldots \ldots \ldots \ldots \ldots \ldots \ldots \ldots \ldots \ldots \ldots \ldots$

Resources and activities ..................... 11

Mandated access ....................... 12

Native American access and issues ............... 12

Public awareness, public relations, education, and user

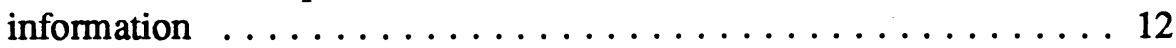

Legal liabilities ......................... 13

Conceptual frameworks .................... 13

Non-DoD Federal management policies . . . . . . . . . . . . 14 
Cultural Resources - Conclusions . . . . . . . . . . . . . . 14

Awareness .......................... 15

Priorities ........................ 16

Access to facilities $\ldots \ldots \ldots \ldots \ldots \ldots \ldots \ldots \ldots$

Issues particular to the level of interaction

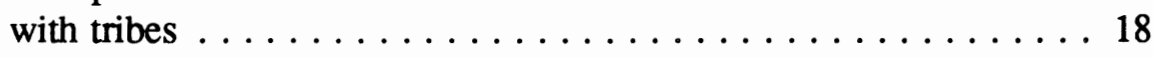

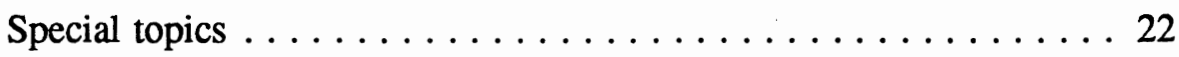

Cultural Resources - Recommendations . . . . . . . . . . 24

References ........................... 27

SF 298 


\section{Preface}

The report herein was prepared as part of the Education, Public Awareness, and Outdoor Recreation Task Area of the Department of Defense Legacy Resource Management Program. The overall program is managed by the Office of the Deputy Assistant Secretary of Defense for the Environment. The Education, Public Awareness, and Outdoor Recreation Task Area is managed at the U.S. Army Engineer Waterways Experiment Station (WES).

Mr. Michael R. Waring, Stewardship Branch (SB), Natural Resources Division (NRD), Environmental Laboratory (EL), WES, is the Task Area Manager.

Dr. Paul R. Nickens, Resource Analysis Branch (RAB), NRD, EL, WES, Mr. Waring, and Dr. Walter H. Bumgardner, School of Human Performance and Recreation, University of Southern Mississippi, Hattiesburg, MS, prepared this report. The work was completed under the general supervision of Mr. Roger Hamilton, Chief, RAB; Mr. Chester O. Martin, Acting Chief, SB; Mr. J. L. Decell, Acting Chief, NRD; and Dr. John Harrison, Director, EL.

At the time of publication of this report, Director of WES was Dr. Robert W. Whalin. Commander was COL Bruce K. Howard, EN.

This report should be cited as follows:

Nickens, P. R., Waring, M. R., and Bumgardner, W. H. (1993). "Summary report: Legacy Education, Public Awareness, and Recreation Task Area," Technical Report EL-93-16, U.S. Army Engineer Waterways Experiment Station, Vicksburg, MS. 



\section{Introduction}

\section{Background}

The Department of Defense (DoD) is custodian of some 25 million acres ${ }^{1}$ of land and water containing valuable natural and cultural resources, making it the fifth largest Federal land managing agency. Additionally, the individual military branches have agreements with States and other Federal land managing agencies, e.g., the Bureau of Land Management and the U.S. Forest Service, which permits use of another 15 million acres in the United States. In recent years, DoD and Congress have become increasingly concerned with the overall management and stewardship of natural and cultural resources located on the many military installations. In 1990, Congress passed legislation establishing a "Legacy Resource Management Program" (LRMP) within the DoD, Office of the Deputy Assistant Secretary of Defense for the Environment. Subsequent funding in the Defense Appropriations Act of 1991 (Public Law 101-511) initiated a broad spectrum of activities designed to support and enhance DoD stewardship of these significant and often irreplaceable natural and cultural resources (U.S. Department of the Defense 1991, 1992). The Legacy legislation specifically directs DoD to give high priority to inventorying, conserving, and restoring biological, cultural, and geophysical resources, using cost-effective and state-of-the-art methods, while at the same time fully integrating these endeavors with DoD's mission activities.

The LRMP was given nine legislative purposes designed to create better integration of resource conservation with the dynamic requirements of military missions. These missions incorporate many activities. Those that affect management of natural and cultural resources most significantly include actions associated with military training, both ground and aviation, base/facility expansion or closure, and management of military lands. Among these legislative purposes, number eight calls for the LRMP "to establish educational, public access, and recreation programs designed to increase public appreciation, awareness and support for these national environmental initiatives" resulting from the overall program.

\footnotetext{
1 To convert acres to square meters, multiply by $4,046.873$.
} 
Completion of the legislative mandates of the LRMP has involved two general types of activities. Ten task areas have been established to undertake the necessary elements of Legacy program development. Concurrently, Legacy-funded demonstration projects are being completed for cultural and natural resource management programs on military installations throughout the United States. In order to accomplish the goal expressed in LRMP legislative purpose number eight noted above, a specific task area on "Education, Public Awareness, and Recreation" was initiated in 1991. Management of the task area was assigned to the U.S. Army Engineer Waterways Experiment Station (WES), Vicksburg, MS. The goal of the Education, Public Awareness, and Recreation Task Area is to develop an understanding of, and framework for, educational, public access, and recreation programs that affect public appreciation, awareness, and support for Legacy initiatives. This goal is being met by addressing the following objectives (U.S. Department of Defense 1991) :

a. Determine resources and activities requiring public access, according to three broad categories:

(1) Cultural resources (e.g., spiritual sites or burial grounds).

(2) Fish and wildlife (primarily hunting, fishing, and management activities).

(3) Miscellaneous activities (e.g., grazing leases, timber activities, scientific study access, and other recreational pursuits).

b. Identify legal liabilities associated with providing access to such resources.

c. Determine potential methods to minimize potential liability.

d. Analyze effectiveness of current DoD public relations, education, and access programs.

e. Develop a conceptual framework for enhancing understanding and appreciation of natural and cultural resources within DoD and by the general public.

\section{Purpose and Organization of the Report}

This report presents a brief summary of the work accomplished within the Education, Public Awareness, and Recreation Task Area in 1991 and 1992. Chapter 2 provides a recapitulation of the personnel involved in the efforts, the activities and procedures undertaken to acquire and evaluate relevant data, and the products. Chapter 3 offers a summation of the conclusions and recommendations resulting from the work unit efforts. 


\section{Task Area Framework}

\section{Management and Personnel}

The LRMP Education, Public Awareness, and Recreation Task Area is managed within the Environmental Laboratory at WES. Mr. Michael R. Waring is the Task Area Manager. For data collection and evaluation purposes, the task area was subdivided into two resource-related subtasks: Natural and Cultural. Dr. Walter H. Bumgardner, School of Human Performance and Recreation, University of Southern Mississippi, Hattiesburg, MS, served as leader for the natural resources subtask. Dr. Paul R. Nickens, Environmental Laboratory at WES, served in a similar role for cultural resources. Dr. Richard W. Stoffle, Bureau of Applied Research in Anthropology, University of Arizona, Tucson, AZ, contributed contractual services to the cultural resources subtask area.

\section{Subtask Area Objectives}

Separate but overlapping objectives were defined for each of the two defined resource categories. These are as follows:

\section{Natural resources objectives}

a. Determine resources and activities providing existing or potential access to the public.

b. Determine what access is mandated, e.g., access by fish and wildlife management agencies.

c. Determine the effectiveness of current public relations, educational, and access programs. Shortfalls and opportunities for improvement are to be identified.

d. Identify legal liabilities and potential methods of minimizing liability associated with providing access. 
e. Develop a conceptual framework for increasing the following:

(1) Public awareness.

(2) Educational programs relative to DoD resources.

(3) Public access.

(4) Programs to increase public use of DoD resources.

f. Address issues related to Native American access to DoD installations relative to the use of natural resources for hunting, fishing, and outdoor recreation.

\section{Cultural resources objectives}

a. Provide a definition of the types of Native American sacred sites that are known to or may occur on DoD installations in the United States.

b. Identify legal and other kinds of issues associated with Native American access to these sites.

c. Evaluate the status of current policies and procedures concerning Native American access to DoD installations, especially as they relate to sacred sites.

d. Provide recommendations for increasing DoD awareness of the relevant issues in this area and for achieving more knowledgeable management and protection of such resources.

\section{Procedures and Methods}

Several approaches and activities were utilized to gather information necessary to meet the defined objectives, including interviewing knowledgeable individuals, installation visits, direct contacts with other Federal and State agencies, literature searches of several computerized databases, and letter and telephone surveys. Another valuable procedure involved attendance and participation at a number of Legacy-sponsored and other workshops, conferences, etc. Between November 1991 and December 1992, one or more of the task area principals participated in following meetings:

a. Legacy Cultural Resources Task Area Working Group: Historic Objects and Archives, November 1991, Washington, DC.

b. Legacy Cultural Resources Task Area Working Group: Traditional Places and Archeological Sites, November 1991, Alexandria, VA. 
c. Legacy Cultural Resources Task Area Working Group: Historic Structures and Landscapes, November 1991, Alexandria, VA.

d. National Park Service Public Awareness Working Group, December 1991, Seattle, WA.

e. Legacy Pacific Area Regional Meeting, April 1992, Honolulu, HI.

f. Legacy Biological Task Area Workshop, May 1992, Denver, CO.

g. Keepers of the Treasures Annual Cultural Heritage and Historic Preservation Conference, October 1992, Polson, MT.

h. Native American Fish and Wildlife Society, South and Eastern Regional Conference, October 1992, Biloxi, MS.

i. Legacy Texas Area Regional Meeting, December 1992, San Antonio, TX.

Additional information on the procedures used to collect data related to the task area topics are more fully discussed in the individual task area reports listed below.

\section{Products}

Aside from this report summarizing the results of the task area efforts, three additional draft reports have been prepared. These reports are:

a. "Final Report: Education, Public Access, and Outdoor Recreation" (Bumgardner, In Preparation).

b. "Native American Access to Religious and Sacred Sites on Department of Defense Installations" (Nickens et al., In Preparation).

c. "American Indian Access to Department of Defense Facilities: Source Documents and Bibliography" (Stoffle, Austin, and Fulfrost, In Preparation).

The summary conclusions and recommendations presented herein are derived from these documents. 


\section{Conclusions and Recommendations}

In this part of the summary report, the primary conclusions reached as a result of the task area efforts are listed, along with various recommendations for increasing awareness of the relevant issues and for enhancing more knowledgeable management and protection of natural and cultural resources on DoD landholdings.

\section{Natural Resources - Conclusions}

\section{Authority and access}

The broad purpose of this research was to examine the existing state of public access to military natural resources and, while being consistent with the goals of Legacy, to explore alternatives for increasing access. The study is limited by the small number of onsite field investigations made to military installations and the number of natural resource managers interviewed. While a number of opportunities have been identified offering potential for increased public access, it is realized that large increases cannot and should not take place "overnight."

Existing Federal laws are for the most part sufficiently comprehensive to enable present use and potentially increased public access to military installations for outdoor recreation, education, and natural resources awareness. However, the United States Congress should consider amending 10 U.S. Code, Section 2668 to permit the Service Secretaries to lease portions of DoD lands to nonprofit organizations for organized outdoor recreation activities such as hunting clubs, off-road recreation vehicle clubs, and camping clubs. Lack of coordination between the two Defense Department entities responsible for recreation programs and natural resource management is suboptimizing the potential effectiveness of Legacy. Modification of DoD policy permitting public civilian usage of certain Morale, Welfare, and Recreation (MWR) facilities would contribute substantially to increased public use and awareness of DoD's vast and varied natural and cultural resources. 
The use of off-road vehicles is an increasingly popular recreational activity of many Americans. The desire of military personnel for this activity is no different from that of the general public. Use of off-road vehicles is not getting much support at either the DoD, the Military Services, or installation levels. Perhaps this is out of concern for possible damage to natural resources. The best way to control the growing interest in the use of off-road recreational vehicles (ORRVs) is to have a program to control it. Sufficient technical information is available that would allow this activity to be more appropriately planned and substantially increased through proper management techniques and controls. Fort Polk, LA, serves as one model of how this activity can be properly confined to specified areas and controlled. DoD's policy on ORRVs on military installations should be reviewed with consideration of adopting a more proactive position closer aligned with the intent of the pertinent Executive Orders. DoD could benefit by showing considerations beyond installation boundaries as a good community neighbor.

Most military installations have been fully or partially surveyed for possible increases of off-post civilian outdoor recreation, but the prevailing attitude among installation personnel who have the responsibility for accomplishing it is more negative than positive. Speculation on a reason for this attitude is that it may relate to the need for further clarification and reinforcement of congressional policy on public use. It also may be reflective of implications increased use would have on inadequate installation staffing.

If DoD were to open installations to more public access, it could encounter the same legal problems experienced by the U.S. Forest Service (USFS) and the Bureau of Land Management (BLM) regarding access rights through bordering private properties. Because of national security concerns, in many if not most instances, there is no reason why increased public use could not be controlled through a few well-monitored points. Other special access arrangements could be made on particular and predictable pieces of land. Nevertheless, some installations are so large that complete control of public access could involve a problem by visitors gaining access through bordering private properties. This is an issue that needs addressing prior to increasing public access on some DoD properties.

\section{Resources and activities}

It is difficult to determine how much DoD land is available for outdoor recreation. Estimated amounts vary among different sources. DoD 1988 Defense Environmental Management Information System (DEMIS) data indicated 10,803,801 acres were available for hunting and fishing and $9,537,498$ acres for other outdoor recreation. Spinks (1991) indicated $10,728,546$ acres were open or partially open to the general public for hunting and fishing. The 1992 Legacy Program Survey of Natural and Cultural Resources Programs sample of 204 installations indicated 3,495,123 acres were available for hunting and fishing and 9,537,498 acres for other outdoor recreation. The total amount available may not be as important as the indication 
that over half of its installations appear to have enough fish and wildlife resources to sustain expanded outdoor recreation programs. Twenty-three installations have the resources, but no outdoor recreation programs.

According to natural resource managers, they are often short of the qualified personnel needed to conduct programs and activities.

While DoD policy specifies there should be equity through impartial procedures for determining public access to its natural resources, its military installations are not applying the policy uniformly. By comparison to the military community, the general public apparently has the least amount of access to DoD natural resources, particularly for hunting and fishing. Lack of consistency in installation practices of admitting the public is prevalent and needs changing.

In addition to clarification of DoD and Service policy on public access, there is need for more guidance and criteria for use by local commanders in making policy decisions on access and use of installation natural resources and facilities. A comprehensive review of personnel staffing requirements and funding at all levels is needed to support natural resources management programs envisioned by the Congress, DoD, and the Services.

Legacy goals of establishing educational/awareness programs and increasing public access to military installations may be in conflict with Government Accounting Office (GAO) policy emphasis on retention of areas and facilities mainly as required to support military missions. This apparently is causing some installations to be reluctant in developing projects that have the appearance of catering too much to the public. This situation, if uncorrected, could diminish the impact and effectiveness of Legacy.

\section{Mandated access}

Cooperation between military installations and State fish and game agencies is mostly very good. One hundred thirty-four cooperative agreements reportedly exist. A few problems were reported, most of which appear related to the need for improved communications. Cooperation with the U.S. Fish and Wildlife Service (USFWS) in establishing and carrying out Sikes Act agreements is even better, one hundred one projects are in place.

\section{Native American access}

DoD, Military Service, and installation policies on Native American access to military installations for purposes of outdoor recreation, hunting, fishing, and gathering activities are sparse to nonexistent. Other Federal land management agencies either have or are in the process of developing applicable policy that could be very useful to similar DoD undertakings. Native Americans have special access needs and rights to military lands that should be acknowledged and assured through DoD policy. A few military installations are forging 
ahead with Native American programs that could serve as examples of DoDwide enhancement of natural and cultural resources management programs. Legislative obstacles exist concerning direct, noncompetitive contracting with Native American tribes for work in installation natural resources management programs. The Native American Fish and Wildlife Society could be instrumental in fostering more cooperating and better communications between DoD natural resource managers and Native American tribes.

\section{Public awareness, public relations, education, and user information}

There is a great need for improved public awareness, public relations, educational, and user information programs concerning DoD natural resource management programs. Unfortunately, there is no well-defined program or procedures for accomplishing this important task. Natural resource managers are fully occupied with management of natural resources and have little time or resources needed for conducting comprehensive, cohesive public awareness, relations, education, and user information programs. Perhaps interpretive and educational specialists should be added to installation natural resource staffs, especially at larger installations. An altemative would be to hire interpretive and educational specialists covering clusters of closely associated installations such as in the Washington, DC area. Fortunately there are some good secondary sources of user information existing that could be more useful through expanded and increased distribution. There is no single approach that covers all of these related but distinct functions in natural resources management. Research is needed on identifying approaches for interacting more effectively with local "publics." Numerous nonmilitary special interest groups are available for assisting installations with natural resources management, conservation, publicity, education, and public awareness initiatives. Local research and establishment of information management systems of the type proposed in this report for Eglin Air Force Base (AFB) are essential for successful programs of this nature.

\section{Legal liabilities}

Legal liabilities for personal injury to members of the public engaged in recreation on a military installation is covered under the Federal Tort Claims Act. The Federal government has the same legal liability as a private individual. However, protection from negligence is provided under the concept of discretionary function immunity where certain criteria are met. In some instances, State statutes influence court decisions involving claims against the Federal government. It is unclear at this juncture of the extent to which there would be a real increase in liability exposure to the military with increased public access to its resources; however, there are measures that can be taken to minimize the likelihood of personal injuries, litigation, and liability. For instance, the rationale for plans and decisions enabling increased public access should be documented in advance. This should include measures taken or not taken to ensure public safety. Adherence to professional standards and codes 
of conduct, awareness, and utilization of the best methods and equipment, and use of competent caring personnel, along with the maintenance of relevant records and forms, will minimize injuries, litigation, and liability.

\section{Conceptual frameworks}

The Chesapeake Bay Area Action Plan, a comprehensive guide for public access to a major multistate natural resource, is the most informative source of information on a regional approach to providing public access to a large natural resource. DoD could use this model in areas with concentrations of military installations near abundant natural resources. This would be a major accomplishment worthy of Legacy support. Opportunities for DoD to increase use of its land and natural resources through existing real property planning and management regulations (i.e., AFR 87-3, 2 FR 34-4, AR 405-80, and NAVFAC P-73) are described and examples are given where this has been successfully accomplished. The DoD and Services have several welldeveloped natural resources management and enhancement programs in place, such as the Air Installation Compatible Use Zone Program (AICUZ), Integrated Natural Resources Management Plans (INRMP), Integrated Training Area Management Program (ITAM), and the Environmental Compliance Assessment System (ECAS), that could be more broadly applied to the benefit of Legacy.

\section{Non-DoD Federal management policies}

A review of management policies of the other major Federal land management agencies was conducted. The National Park Service (NPS) policies pertaining to off-road vehicle use, snowmobiles, accessibility for disabled persons, visitor safety and protection, emergency preparedness and emergency operations, law enforcement, emergency medical services, fees and charges, and special park uses and events are worthy of consideration by DoD in formulating similar policies. The NPS interpretation and education program could serve as a model for structuring similar DoD programs. BLM's management policies and land classification system have features worthy of adoption by DoD. BLM's classification of authorized resource uses also could provide insight to development of a similar DoD system. If DoD would utilize the USFS Recreation Opportunity Spectrum (ROS) system more widely, this could establish it on the same level with other Federal land management agencies involved in outdoor recreation planning. Incorporation of USFS Recreation Information Management system features could improve DoD's DEMIS. DoD application of USFWS approaches to public education could advance Legacy goals. Any formulation of DoD policy on Native American access should involve thorough review of existing NPS, BLM, and USFS policies on the topic, and especially that being drafted by the USFWS. The policy being formulated by the USFWS provides guidance on many situations likely needing attention by DoD. DoD use of approaches similar to those used by the Bureau of Reclamation for providing handicapped people access to natural and 
cultural resources could enhance the goals of legacy and reflect favorably on DoD.

\section{Natural Resources - Recommendations}

\section{Authority and access}

More coordination in formulation of DoD policy pertaining to outdoor recreation should take place between the Office of the Deputy Assistant Secretary of Defense (Personnel, Families, Education, and Safety) and the Deputy Assistant Secretary of Defense (Environment). The DoD Directive on MWR Programs and Nonappropriated Funds should be revised permitting non-DoD civilians usage of outdoor recreation facilities such as marinas, campgrounds, parks, and other facilities on a space-available basis, to facilitate increased public usage of DoD natural resources. The changes should be reflected in revisions to DoD Directive 4700.4, Natural Resources Management Program.

More support should be given at all levels for increased access to DoD natural resources through a well-planned and coordinated off-road vehicle program using technology and information obtainable on similar programs through the other Federal land management agencies.

The purpose, goals, and objectives of Legacy need more publicity and promotion within DoD to improve attitudes among installation level DoD personnel, and their supervisors, toward increased public inclusion in DoD outdoor recreation programs and activities. If the Department of Defense decides to increase substantially public access to its natural and cultural resources, it should first review the problems encountered by the USFS and the BLM concerning public access rights through bordering private properties.

\section{Resources and activities}

Improved methods of documenting and reporting the amount of acreage existing under direct DoD control and indirect control through other Federal land management agencies should be implemented. Outdoor recreation programs should be developed at installations that have none, and programs should be increased at installations that have the capacity for expansion.

Existing DoD policy on determining public access through impartial procedures should be enforced, and all installation policies, practices, and procedures for permitting public access to DoD natural resources should be made consistent. Public use and access plans should be required elements of the Integrated Natural Resources Management Plan of each DoD installation.

Installation commanders should be provided improved DoD and Services criteria, information, and/or guidance for making policy decisions when local 
questions or issues arise concerning public access to installation natural resources.

The potential conflict between Legacy goals and U.S. GAO emphasis on limiting areas and facilities to military mission support should be reviewed and resolved.

\section{Mandated access}

The Department of Defense should maintain agreements with the USFWS and potentially increase Sikes Act agreements. The Military Services should continue working effectively with States. Installations should improve communications with State fish and game departments concerning access to natural resources and increase agreements for management, conservation, and harvesting of fish and game resources.

\section{Native American access and issues}

DoD should develop and implement policies regarding Native American access to military installations for outdoor recreation, traditional cultural, and subsistence purposes. Legacy demonstration projects involving cooperative efforts between Native Americans and management or improvement of DoD natural resources should be undertaken. Legislative obstacles concerning direct, noncompetitive contracting with Native American tribes for work in DoD natural resources management programs should be alleviated. Possible alternatives for accomplishing this would be as follows: (a) amend the Competition in Contracting Act to give an exemption to it for contracts with Indian tribes in or near the reservation, and allow military installations to negotiate contracts directly with local tribes, or (b) create a "set aside program" through the Small Business Administration similar to that contained in the Buy Indian Act.

\section{Public awareness, public relations, education, and user information}

DoD should establish a comprehensive public awareness, public relations, education, and user information system for natural resources. The program should strive to educate the public on its efforts concerning natural resources. The full range of resources and conditions for decisions should be identified. It should also promote the distribution of Spinks (1991) and Crawford (1992) for increasing public as well as military and DoD civilian personnel awareness and access to natural resources and outdoor recreation programs. DoD should assist in the promotion and distribution of the Chesapeake Bay and Susquehanna Public Access Guide (Commonwealth of Virginia 1989). Military installations should be encouraged to submit applications for recognition of exemplary natural resources programs and projects to Renew America's Environmental Success Index. Fazio and Gilbert (1986) should be made 
available to all DoD natural resource managers to use as a guide in formulating local programs. DoD should seek to have appropriate public, military, and DoD civilian-related user questions included in the National Survey of Fishing, Hunting, and Wildlife Associated Recreation conducted periodically by the USFS. DoD should either establish its own database like LEAP (Knoll 1990) or take leadership in establishing a database that would also serve the needs of other Federal land management agencies. Installations should work more actively with organizations like Ducks Unlimited, Trout Unlimited, Pheasants Unlimited, Whitetails Unlimited, Wildlife Trust of North America, Nature Conservancy, National Wild Turkey Federation, National Wildlife Federation, Wildlife Management Institute, USFS, and the Native American Fish and Wildlife Society to improve, promote, and publicize natural resources management programs. Research, public awareness, and education should be supported and conducted.

\section{Legal liabilities}

Natural resources users safety should receive priority consideration and be addressed at the DoD, Service, and installation levels. Clear operational details in Department policy and guidelines need to be established in advance of increases in public use. Policies on emergency services, resource and visitor protection, and closures and restrictions need to be developed. A permanent DoD natural resources user safety policy board should be formed. One of the board's functions should be to review prior accidents and those that happen periodically to plan for whatever precautions are deemed appropriate and necessary to prevent or minimize recurrences. Operational guidelines need to be developed for detecting and responding to emergency situations involving natural resources users. Personnel working at natural resources field levels should be certified through the American Red Cross in standard first aid and adult cardiopulmonary resuscitation. Safety standards consistent with good safety practices and law should be devised and followed. Advance policy decisions need to be made indicating the rationale for when to warn users of situations and when to institute safety precautions. Safety hazards should be minimized. Natural resource users should be warned against safety hazards and dangerous situations by using effective communications methods. Natural resource managers should be trained on the Federal Tort Claims Act and the provisions and conditions for discretionary functional immunity from liability. It is recommended that Koslowski's (1993) Federal Recreation Liability Video Series be used as a training aid for people being trained in liability matters concerning recreation on Federal property.

\section{Conceptual frameworks}

DoD leadership in initiating public access plans and guides like the Chesapeake Bay Area Action Plan in other nationally suitable locations would be a very worthwhile Legacy endeavor. The Military Services should become much more active in utilizing real property planning and management 
regulations for making property available to local public and private agencies for increasing outdoor recreation. Within DoD and the Military Services, there are many good natural resources management related programs, such as AICUZ, ITAM, ECAS, and INRMP and ROS that should be utilized more pervasively to the advantage of Legacy.

\section{Non-DoD Federal management policies}

DoD, the Military Services, and installations should work more closely with other Federal land management agencies to improve natural resources management programs on military installations. Establishment of a policy formulation/coördination committee between DoD and the major Federal land management agencies should be established during this transitionary period of DoD policy formulation.

\section{Cultural Resources - Conclusions}

Efforts in the cultural resources subtask area focused solely on the issues related to Native American access to known or potential religious sites on DoD installations. The designation "Native American" used herein is taken to include all Federally recognized Native American, Native Alaskan, and Native Hawaiian Tribes and organization. Consideration of Native American access and consultation in other matters, as well as resources associated with settler communities, is being evaluated in other LRMP Task Areas, e.g., the Cultural Resources Task Area and the Native American and Settler Communities Task Area, in addition to the emphasis on Native American access to natural resources in the previous discussion. The ensuing summary reviews the findings of the work effort, followed by a set of recommended activities designed to enhance DoD stewardship of these valuable resources and foster improved interaction and consultation between DoD and the affected Tribes.

Properties that Native American groups consider to be religious or sacred include a variety of site types. According to one classification, such sites may include the following: burial grounds and graves; purification sites; healing sites; special flora and fauna sites; unique quarries; vision questing and dreaming places; mythic and legendary sites; temples and shrines; places of spiritual renewal; astronomical observatories; and historical sites of importance to the group or individuals.

These sites, along with other types of cultural resources, are protected by a suite of Federal laws, including the National Historic Preservation Act (NHPA), the National Environmental Policy Act (NEPA), the Archeological Resources Protection Act (ARPA), the American Indian Religious Freedom Act (AIRFA), the Native American Graves Protection and Repatriation Act (NAGPRA), and other related public laws and Federal regulations. These laws 
and regulations are supported by individual DoD service regulations and policies.

The strongest of these laws in terms of compliance activities are NEPA, NHPA, and ARPA. However, in terms of access to religious and sacred sites, none of these acts specifically leads to access for Native Americans to sites on DoD installations. AIRFA, on the other hand, states that it is the "policy" of the United States government to protect and preserve for Native Americans the right of freedom to believe, express, and exercise their traditional religions. These rights specifically include access to sites. The more recent NAGPRA incorporates access rights of a different nature, namely access to curated human remains that have been excavated from Federal agency lands, along with other related cultural materials such as associated and unassociated funerary objects, sacred objects, and objects of cultural patrimony. It would appear that implementation of the provisions of this act will likely also include direct access to in situ Native American burials and cemeteries in the future as part of consultation activities.

Presently, only the Air Force has a document that deals specifically with Native American consultation, including access to culturally important sites. This document, however, was issued as "guidelines"; thus individual Air Force units may elect not to follow them. They are also not applicable to the other services.

In spite of the absence of specific policies or guidelines, a few installations around the country have initiated novel consultation efforts granting Native American access to religious and sacred sites, or to natural resources of such significance. These installations and their agreements can serve as models for others.

A survey of military installations designed to obtain information about existing Native American access agreements and related issues resulted in a number of conclusions. These are briefly outlined below.

\section{Awareness}

At many facilities, the subject of Native American, Native Hawaiian, or Native Alaskan interaction was unfamiliar to most people other than the archaeologist or cultural resource officer. Telephone operators, public affairs officers, and persons in environmental management were frequently unable to identify the persons at their facility who would have responsibility for this information. Several persons who believed they were the ones responsible for handling the dissemination of information or requests for access to the facility nevertheless expressed uncertainty about how to respond to the questions they were asked. Also, although several public affairs officers stated that their office would be a point of contact to the facility for tribal members, there is no central or uniform point of contact from one facility to another through which information about native access can be gathered. Several respondents 
remarked that they had never before had requests for this type of information. In addition, at several bases, the individuals were unaware of their department's policy regarding native groups or of a larger structure of which they were a part and to which they could turn for more information on this particular subject. Other than archaeologists or designated cultural resource managers, only two Air Force contacts mentioned any knowledge of recent communication from Air Force Commands regarding AIRFA or NAGPRA.

Though a lack of awareness was common at bases without relationships with tribes, this also proved to be a problem at some bases with existing agreements or documents that specifically addressed native interactions. Unless a named cultural resource manager could be located, the caller was often shuffled from office to office. This uncertainty among base personnel creates a potentially significant problem for tribal members who would contact a facility seeking information or access.

Reasons identified for the lack of awareness include the high turnover rates and short time that many individuals had been in their positions. New employees generally knew nothing about the interactions occurring on their bases. A standardized system for handling these issues within the military departments would facilitate information transfer.

\section{Priorities}

Native American issues have not received much attention at many of the bases contacted. Native concerns have not been given priority among the competing demands facilities face. Several contacts remarked that their bases had been dealing extensively with hazardous wastes and related issues on which they have received pressure to address. They reported that under the existing circumstances, little attention had been given to interactions with native groups because of the absence of pressure in that direction. Some contacts indicated they believe that military installations have tried to ignore the native issues as much as possible. They acknowledged past failures to take these issues into account or to contact tribes when it would have been appropriate. One individual commented that native groups should be involved early in consultation activities, preferably before a proposed action when people are already upset. Several observed that military installations need to incorporate individuals sensitive to native concerns and familiar with the involved tribes, who have prior experience working with native people rather than relying on personnel who may not have any experience in this area.

A few facilities have had extensive involvement with native groups. Much of that has grown out of a trial and error approach to issues that have been raised by tribal members. Even where there is attention to native issues, though, most has been focused on archaeological sites and artifacts with little attention to consultation with tribes over other cultural resources. The few exceptions will be discussed in greater detail in the next section. 


\section{Access to facilities}

Native Americans seek access to military facilities for a number of reasons. Two of the most commonly stated purposes are visits to sacred sites in order to conduct ceremonials and visits to harvest plant or animal resources.

Policies and procedures regarding Native American access to DoD facilities are not uniform. Access has generally only been incorporated into formal agreements and policy statements where these issues have been a problem. Two Army bases, one naval station and one Air Force instalkation have particular agreements or policies to facilitate access by native people. For example, a Memorandum of Agreement (MOA) between the Commander Naval Weapons Center and the Coso Ad Hoc Committee of the Owens Valley PaiuteShoshone Band of Indians reserves eight weekends per year exclusively for visits by members of the Owens Valley Paiute-Shoshone Band of Indians and/ or the Kern Valley Indian Community to Coso Hot Springs, located within the Naval Weapons Center, China Lake, CA.

Generally, contacts stated that Native American access issues that might arise would be handled through the facility's general access policies applicable to all persons, or dealt with informally. Native requests for access are handled through normal public relations procedures or in some cases through the museum director's office. For example, an area of sand dunes that is considered sacred by some Native Hawaiian people is located within naval property on Kauai. No formal agreements provide for visitation by Native Hawaiian people, but the base has a fairly open access policy requiring only that visitors sign in at the gate. At Fort Wainwright in Alaska, where access to game harvest has been an issue, procedures concerning access to hunting grounds are the same for any citizen, regardless of whether the citizen is a native with traditional subsistence ties to land on the facility.

Some policies have become institutionalized but nevertheless remain informal. For example, Fort Huachuca allows Apache people to harvest nuts at the fort in what was described as a "traditional" agreement between the tribe and the base. Lack of formal procedures governing access appears to be typical for facilities where access to botanical, sacred, or other cultural sites have been issues. Also, access has been granted at many installations as a result of informal agreements associated with construction projects like the Army's Facilities Construction Program of 1941 and 1942 during which many installations were built over burial sites.

Some contacts reported that they had never received any specific requests for access even when there were culturally significant sites at their facility. There are several cases where native tribes have come on to the installations to investigate discovered archaeological or cultural sites but have not specifically requested access to the sites. At some locations, there appears to be greater interest among anthropologists than native groups regarding culturally significant sites. For example, Lone Rock at the Navy's Bravo 20 Target Range in Nevada has been identified by anthropologists as a feature in Paiute 
mythology, but native groups have not contacted the naval offices with concerns. Formal contacts with the tribes in the region regarding their interest in the site are now beginning as part of an environmental assessment of the range.

\section{Issues particular to the level of interaction with tribes}

Access to military facilities is a particular area of concern for Native Americans. However, interaction with DoD departments also involves access to information about artifacts and archaeological resources discovered on military properties and consultation regarding those and other cultural resources. Most military facilities with sites of archaeological or cultural significance to native peoples have no formal agreements or policies that specifically address either Native American access or consultation. Interactions with Native Americans at these facilities are usually dealt with through normal public relations procedures or through informal, nonbinding agreements with native groups. For example, Fort Sam Houston will enter into consultation with any "interested parties" in order to comply with the requirements of Section 106 of NHPA, but Native American groups receive the same treatment as other public groups with whom base personnel interact. Where consultation relationships exist, these are often included within procedures or policies related to environmental assessments, environmental impact statements, natural or cultural resource management plans, historic preservation plans, or programmatic agreements generated through the Section 106 process. For example, Redstone Arsenal in Alabama has an MOA with the State Historic Preservation Office (SHPO) regarding the protection and management of historic properties on the facility that indicates a need to consult with "interested parties" including Native American groups.

Though memoranda of agreement regarding archaeological and historical sites exist at several facilities, they do not always require consultation nor are they agreements with the affected native groups. Many of these agreements incorporate native groups as "interested parties." Other facilities, without MOAs or Memorandum of Understanding (MOU), send informal letters of consultation to native groups regarding proposed projects or excavations. For example, White Sands Missile Range sent a letter of consultation to the Mescalero Apache Tribe as part of an Environmental Impact Statement (EIS) for its Aerial Cable Test Capability Project. These formal agreements or informal letters of consultation are usually completed in order to fulfill the requirements of NHPA, AIRFA, NAGPRA, and other relevant laws. Such policies are not native-specific and do not recognize the particular interest of identified Native American groups to specific sacred sites. Therefore, for the purposes of this report, they are treated separately from the agreements and policies that are specific to particular Native American groups.

Where Native American sacred sites are present at DoD facilities, there are also differences in the degree of interaction that personnel there have with native groups. The issues that were raised by contacts at each facility were 
often related to the level of interaction that the facility had with native groups. The extent of interaction has been divided into four levels. Facilities at Level One have had no interaction with Native American groups. Facilities have been included at Level Two if their interactions with native groups have been limited to informal meetings or minimal contact with native groups regarding cultural resources. Facilities have been included at Level Three if they have had sustained interactions with Native American groups, but they do not have formal policies or agreements specifically with or naming those groups. Finally, facilities with formal agreements and policies that govern interactions with Native American groups and are specific to those groups have been included at Level Four.

Level 1: Facilities with known sites but no interactions with Native American groups. Twenty-three percent of the facilities with known sites that were contacted have no interaction with Native American groups. Several of these have no mechanism for contacting tribes. Some of these contact archaeologists or SHPOs directly if they discover artifacts or sites. Contacts reported that they have curated artifacts not presently receiving attention or Indian mounds that they have agreed to leave undisturbed. At most facilities, there appears to have been little archaeological research done. These facilities generally have not completed the surveys of the land under their jurisdiction. It is anticipated that further research in this area will result in increased concern for consultation and access issues. In some cases, contacts reported that they had policies that would lead them to treat Native Americans as "interested parties" in consultation, but they had never contacted native groups under those policies. The Historic Preservation Plan (HPP) for Redstone Arsenal in Alabama includes a requirement to consult with Native Americans when burials are discovered; however, they have not reached this consultation stage.

Individuals at several facilities reported that they recognized the deficiencies in their existing programs, but did not have the resources to devote to improving the situation. Several are waiting for a response to monetary requests they submitted as part of their proposed Legacy projects that would specifically address the archaeological or cultural resource issues at their facilities. One such proposal is the request for resources for the completion of surveys of the test and training ranges at Hill Air Force Base in Utah.

Level 2: Facilities with limited interactions with Native American groups. One-third of the facilities contacted had only limited interactions with Native American groups regarding known sacred sites or cultural resources. These interactions include informal meetings or isolated contact with native groups. Facilities with limited interactions may have developed MOAs or Cultural Resource Management Plans (CRMPs) that require the base to contact native groups regarding cultural resources, but they have not received any responses nor have they attempted to initiate further interaction. For example, Fort Sam Houston in Texas sent out letters of consultation to Native American groups as part of the facility's CRMP requirement to consult with "interested parties." This stipulation was created in order to fulfill the consultation 
requirements of the NHPA. The base has never received any responses from these consultation letters.

Several facilities that have been slated for closure under the Base Realignment and Closure (BRAC) procedures have discovered sacred sites or artifacts in the environmental impact studies required at all such facilities. In most cases, these facilities have had no prior interactions with Native American groups; but these have been identified and contacted, or efforts are underway to contact them as a result of those finds.

A number of facilities are in the process of trying to improve communication with identified native groups in their area. Contacts reported they had initiated some interaction or had intentions to send letters and hold meetings with native representatives. For example, the presence of cultural resources at the Goldwater Air Force Range under the jurisdiction of Luke AFB has led base personnel there to announce at a public forum the intention to try to incorporate Native American input into their cultural resource management planning. Input has not yet been solicited.

At some facilities where sites exist, there are no regular interactions with tribes because no Native American groups have expressed interest in the area. Also, contacts at a few facilities felt that their attempts with either the tribes or umbrella organizations such as the Native American Heritage Commission (Califormia) have been ignored. They have not received responses to requests for information or involvement. The lack of response requires further investigation.

Some contacts expressed a need for clarification of the treaties presently in force with native groups and the current legal situations regarding who must be contacted as required by Federal laws and regulations. In addition, concern was expressed over what to do and who to contact when facilities are located in areas with few remaining tribes or with groups that have not achieved Federal government recognition. Several individuals requested copies of reports, examples of existing agreements, or other information to use as guidance in developing their Native American programs.

Level 3: Facilities with sustained interactions with Native American groups not governed by specific native agreement or policies. Twenty-three percent of the facilities contacted have had more sustained interaction with Native American groups. These facilities have been involved with Native American groups on an ongoing basis regarding access, reburials, cultural resource assessments, etc. They have had multiple contacts with these groups as relevant issues have arisen at their facilities. Nevertheless, these facilities have no agreements or policies that are with or specific to particular Native American groups. For example, interactions with tribes at Mountain Home AFB are handled through that base's contractor and include involvement since 1989 with the local Shoshone and Bannock tribes to fulfill NEPA requirements as well as recent contacts with those tribes regarding a proposed bombing range expansion. Recently, a liaison has been established at the base to 
interact with persons at the Duck Valley Indian Reservation regarding aircraft flyovers. As another example, Fort Carson in Colorado has an MOA with SHPO and the Advisory Council for Historic Preservation (ACHP) regarding historic properties that requires consultation with "interested parties," including Native Americans. The facility has consulted with native groups on at least two occasions in order to fulfill its legal requirements under NHPA and NAGPRA.

At some facilities, informal interactions take place with nearby nonrecognized native groups. Contacts at some of these locations have indicated that they plan to seek out and establish contact with officially recognized tribes that have historical ties to the military properties but were relocated to other areas in the past. For example, personnel at Eglin AFB in Florida have informal agreements with a local Native American group that is attempting to obtain Federal recognition but intend also to contact three Federally recognized tribes, including tribes now living outside Florida, for future consultation.

For Sill in Oklahoma is in a unique situation because personnel there have had extensive informal interactions with native groups but are only now in the process of developing formal agreements with specific Native American tribes. These formal agreements concern Native American access to and consultation over burial grounds located on the base.

Level 4: Facilities with formal agreements/policies specific to native groups. Twenty-one percent of the facilities contacted have developed either formal agreements with specific native groups regarding access or consultation, or they have formal agreements or policies that require consultation with specific native groups. Formal agreements between military facilities and specific native groups regarding archaeological, historical, or other cultural resources have generally taken the form of memoranda of understanding or agreement. These agreements specify and describe native consultation procedures for the treatment of culturally significant properties found on the facilities. When the agreement concerns human remains, issues of access to the reburial sites are often incorporated in these agreements.

A few facilities have full Native American participation in consultation and the development of procedures to facilitate access. The policies at these facilities include MOAs, MOUs, HPPs, and agreements with individual tribal members and tribal councils. One such program exists at Vandenberg Air Force Base, CA, where a comprehensive program has developed over a 15-year period. The interaction involves the facility and the Santa Ynez Band of Mission Indians, incorporating both representatives of the tribal council and individual tribal members.

Another example of extensive interaction between a military facility and Indian groups regarding access is Fort Lewis in Washington. This military base has a formal policy regarding Native American access to the facility. In addition to this Native American access policy, the base has an MOA with the Yakima tribe and an MOA with the Nisqually tribe regarding access to and use 
of lands on the facility and its accompanying training center. The base has also sent a letter of agreement to the Wanapum tribe that allows them access to the facility for purposes of hunting, fishing, gathering, and conducting ceremonies.

Where access has not yet become an issue, formal agreements or policies pertaining to specific Native American groups usually require consultation over cultural resources. Archaeological and ethnographic research is often conducted on military facilities as part of EISs, CRMPs, HPPs, or even Natural Resource Management Plans in order to identify sides that are culturally significant to Native Americans.

Some facilities require consultation with native groups through stated consultation relationships found within CRMPs, MOAs, MOUs, or related documents. The Navajo Army Depot in Arizona has an MOA with SHPO requiring that its CRMP be prepared in consultation with a number of specific tribes. The Yuma Proving Grounds in Arizona has an MOA with SHPO and ACHP that also requires consultation with a number of specific tribes.

Though many of the military facilities contacted acknowledged that little archaeological research had been completed at their locations, a few have done extensive work. An example of a developed research program is that of the Naval Air Weapons Station, China Lake, CA. As part of the program, meetings have been held to discuss NAGPRA compliance, and a NAGPRA implementation plan and bibliography of archaeological and cultural resource surveys particular to that site have been prepared.

\section{Special topics}

A few issues are presently being faced by certain military installations and warrant special attention. These include (a) the process of Base Realignment and Closure, (b) involvement with other government agencies, (c) withdrawn lands, (d) lands returned to Native American groups, and (e) concern with aircraft flyovers.

Base realignment and closure. BRAC procedures have caused many facilities to consult with native groups over issues of access or consultation in archaeological surveys, often for the first time. Environmental impact studies are underway at facilities undergoing or recommended for closure. Future research and consultation associated with programs like BRAC were cited as reasons why access issues are expected to become more prevalent in the next few years. Examples include the interaction with the Narraganset Tribe and the Naval Battalion Center in Davisville, RI, over burials discovered there and the MOA at the Yuma Proving Grounds that was proposed as part of BRAC construction there and spelled out the facility's obligation to concemed Native American tribes. 
Involvement with other government agencies. The activities at several facilities regarding archaeological or cultural resource projects have required the involvement of government agencies in addition to the military organizations. In some cases, the responsibility for native interaction has been left solely to the nonmilitary agency. Examples of interagency involvement include the activities regarding the bombing range expansion that involve the Air Force, the Bureau of Land Management and the State of Idaho, the management of a Native Alaskan burial site on the Adak AFB property by the U.S. Fish and Wildlife Service, and the interaction between Air Force facilities and the National Park Service at several locations. In addition, the need for expertise regarding cultural resource issues has led to an agreement assigning the U.S. Army Corps of Engineers office at Mobile, AL, to act as the cultural resource advisors for Headquarters Marine Corps and an MOA between the St. Louis District of the U.S. Army Corps of Engineers and Naval Air Weapons Station, China Lake, for technical assistance in the inventory and evaluation of Federally owned and administered archaeological collections at that facility.

Interactions between military installations and State agencies have generally involved the SHPOs of the States in which the facilities are located. Within the Northern Division Naval Facilities Engineering Command, for example, naval interactions are with the SHPOs as governed by Executive Order 12372, "Intergovernmental Coordination of Federal Programs." The SHPOs then contact the tribes as needed. Neither the Navy nor the Northern Division Command have entered into any agreements directly with tribes for either the exchange of information or coordination of efforts. Because of the extensive military activity within the State of Nevada, a comprehensive report, the "Special Nevada Report," is available there. That report contains a description of defense-related activities in the State of Nevada as required by the Military Lands Withdrawal Act of 1986.

Withdrawn lands. Nonmilitary land in the United States has been used for military activities in several places. To provide clear legal authority for military use of such land in four states, the Military Lands Withdrawal Act was passed November 6, 1986. The withdrawn lands require special attention with regard to Native American concerns; several individuals at the military bases contacted referred specifically to the withdrawn lands under their jurisdiction. As required by the Act, by 1998, the Secretary of each concerned military department must publish a draft EIS, consistent with the requirements of NEPA, for any withdrawn lands for which that Secretary intends to seek continued or renewed withdrawal. The completion of an EIS will require that the Secretary invite the participation in the scoping process of any affected Native American groups. Withdrawn lands with known sites of interest to Native Americans include the Bravo-20 Bombing Range in Nevada, the Nellis Air Force Range in Nevada, the Barry M. Goldwater Air Force Range in Arizona, and the Fort Wainwright Maneuver Area in Alaska.

Lands returned to Native American groups. Several military properties are being returned to States or other Federal agencies and subsequently to 
Native American groups. For example, the Koho'olawe Training Area in the Hawaiian Islands is being turned over to the State of Hawaii. Similarly, Fort Richardson in the state of Alaska is on the list of bases facing possible closure. Native corporations have top-filed on this land as part of the Alaska Native Claims Settlement Act. At closure, the base will probably be returned to these native groups. The property transfers may require special attention.

Aircraft flyovers. Aircraft flights over native lands were identified by contacts as a problem in several locations. High-speed low-altitude military aviation training missions that fly close to the contour of the ground can have a significant impact on cultural resource management. Since military flyovers occur over large areas beyond military installation boundaries, the potential for widespread impacts of this sort are great. Flying missions can also lead to access restrictions on military lands for various types of sacred sites such as plant collecting areas or fasting/meditation places. This type of restriction at Naval Air Station Falon in Nevada hampers Native American access to a highly significant curing rock and ceremonies conducted there. This subject has been the focus of a recent resolution by the National Congress of American Indians asserting tribal regulatory authority over the airspace above Native American lands.

\section{Cultural Resources - Recommendations}

The recommendations offered regarding Native American, Native Hawaiian, and Native Alaskan access to religious and sacred sites on DoD installations are as follows:

a. The first step in the process is recognition by the DoD of Native American groups' rights. As noted earlier, the Air Force is the only branch of service with written guidelines for Native American consultation, although implementation of this guidance is optional at the installation level. Clearly, policy statements or regulations with implementing regulations are essential at three levels:

(1) DoD, where a statement should be prepared for the signature of the Secretary of Defense.

(2) Service level, where each branch of the military should build on the Secretary's policy statement with regard to its own mission and requirements.

(3) Installation level, where the policy and procedures must be effectively implemented.

$b$. The second step involves identification of the interested parties and their concerns. Each installation within the DoD framework needs to identify those native groups or individuals who have a legitimate 
interest in traditional sites on lands under its control or use. This may include both land within the military reservation boundaries and other lands, both public and private, that may be affected by DoD actions.

It has already been proposed within the LRMP that computerized databases be developed for each installation for Native American consultation needs (Briuer and Hebler 1992). The database would be incorporated within a geographic information system format and include various types of data; for example, maps and information on Federal lands, treaty rights and other legal considerations, maps and information describing the evolution of tribal lands through history, and an electronic bulletin board.

Development of such a database at both national and installation-specific levels is critical to future success in DoD/Native American consultations. The various data in the system will have to be derived not only from documentary sources, but also through effective interaction with the affected tribes as well.

c. Once the affected parties are identified at the installation level, the next step is to achieve understanding of the issues on both sides. Programs to enhance awareness, education, and relations between military commanders/resource managers and affected Native American/ Hawaiian/Alaskan groups are essential to finding compatibility between the various values and needs. Without a doubt, some areas of conflict between military needs and native group concerns will arise. The differences between military needs for security purposes and Native American desires for religious confidentiality is but one of these potential access conflicts. Training scheduling and ceremonial calendars is another one. In the end, effective training/education programs will be necessary to sensitize each side to the other's needs.

d. Concurrent with the above programs, effective management practices for traditional and sacred properties must be developed within each branch of service and installation historic preservation programs. It can be fairly stated at this time that virtually no DoD installation or activity manages these types of resources in a completely effective manner. It must be noted, however, that good starts in this direction can be found at some facilities, as discussed in the previous chapter. DoD should undertake a major effort to improve and implement its identification and management of such sites, along with boosting its interaction with native groups as part of the process.

In addition to a current lack of policies and procedures, there is a broadly based lack of awareness on many of the central issues at the installation level. Military personnel are not aware of who should, or how to, handle situations related to access concerns, and there are no established points of contact for concerned Native American organizations or individuals. Part of the education and effective management processes needs to create personnel at each installation who are knowledgeable about the issues and the procedures for addressing them. 
Proper identification of the resources is paramount. It is just as necessary. to firmly establish that native religious or sacred sites are not present at a given facility. It is not justifiable today to simply assume that just because an issue has not been raised, there are none in existence. This type of management attitude reflects the presence of a reactive management program. Such issues need to be fully identified, evaluated, and integrated into installation management and planning.

Completely acceptable procedures for proper identification and handling of Native American religious and sacred sites have yet to be developed. Certainly, Native Americans themselves must be thoroughly involved in the process. It is not enough to simply rely on archaeologists, anthropologists, historians, or other non-Indian specialists. At the same time, military personnel must be careful that all issues important to a given tribe are identified, not just those vital to selected factions or individuals. Proper site identification methodologies should be developed as part of the consultation leading to meaningful policy and procedure statements at the service and installation levels. In some cases, the methods may have to be region-, tribe-, or installation-specific, because of the types of issues.

Once identified, religious and sacred sites on DoD lands must be managed in a manner that provides Native American access and use within the context of the military mission. While achieving this mission is critical, it should not be accepted without complete evaluation of the situation that it supersedes any other value. For example, is it absolutely necessary to conduct a given type of training at a specific locale on a particular date if a significant conflict with a Native American sacred place or scheduled ceremony is present? Consultation and cooperative interaction will likely result in the realization that the needs of both groups can be met if the mutual concerns are understood and the land is effectively managed. It may be, for example, that once a sacred site is identified, a buffer zone needs to be established to enhance the preservation of the site, protect its sanctity, and allow ceremonies to take place uninterrupted. 


\section{References}

Briuer, F. L., and Hebler, G. A. (1992). "Directory for Native American consultation," U.S. Army Engineer Waterways Experiment Station, Vicksburg, MS.

Bumgardner, W. H. "Final report: Education, public access, and outdoor recreation," Contract Report in preparation, U.S. Army Engineer Waterways Experiment Station, Vicksburg, MS.

Commonwealth of Virginia. (1989). "Chesapeake Bay and Susquehanna public access guide," Virginia Department of Conservation and Historic Resources, Division of Planning and Recreation Services, Richmond, VA.

Crawford, W. R. (1992). "Military RV, Camping and Rec Areas," Military Living Publications, Falls Church, VA.

Fazio, J. R., and Gilbert, D. I. (1986). Public relations and communications for natural resource managers. Kendall/Hunt Publishing Company, Dubuque, IA.

Knoll, P. C., ed. (1990). "Listing of education in archeological programs: The LEAP ClearingHouse, 1987-1989 summary report," U.S. Department of the Interior, National Park Service, Washington, DC.

Nickens, P. R., Stoffle, R. W., Austin, D., and Fulfrost, B. "Native American access to religious and sacred sites on Department of Defense installations," Technical Report in preparation, U.S. Army Engineer Waterways Experiment Station, Vicksburg, MS.

Spinks, J. L. (1991). Hunting and fishing on military lands. Stackpole Books, Harrisburg, PA.

Stoffle, R. W., Austin, D., and Fulfrost, B. "American Indian access to Department of Defense facilities: Source documents and bibliography," Contract Report in preparation, U.S. Army Engineer Waterways Experiment Station, Vicksburg, MS. 
U.S. Department of Defense. (1991). "Report to Congress: Legacy Resource Management Program," Office of the Deputy Assistant Secretary of Defense for the Environment, Washington, DC.

(1992). "Report to Congress: Legacy Resource Management Program," Office of the Deputy Assistant Secretary of Defense for the Environment, Washington, DC. 
Public reporting burden for this collection of information is estımated to average 1 hour per response, including the time for reviewing instructions, searching existing data sources. gathering and maintaining the data needed, and completing and reviewing the collection of information. Send comments regarding this burden estimate or any other aspect of this collection of information, including suggestions for reducing this burden. to Washington Headquarters Services. Directorate for Information Operations and Reports, 1215 Jefferson Davis Highway, Suite 1204. Arlington, VA 22202-4302, and to the Office of Management and Budget, Paperwork Reduction Project (0704-0 188), Washington. DC 20503.

\begin{tabular}{|l|l|l|}
\hline 1. AGENCY USE ONLY (Leave blank) & $\begin{array}{l}\text { 2. REPORT DATE } \\
\text { August } 1993\end{array}$ & $\begin{array}{c}\text { 3. REPORT TYPE AND } \\
\text { Einal renort }\end{array}$ \\
\hline
\end{tabular}

4. TITLE AND SUBTITLE

Summary Report: Legacy Education, Public Awareness, and

Recreation Task Area

6. AUTHOR(S)

Paul R. Nickens

Michael R. Waring

Walter H. Bumgardner

7. PERFORMING ORGANIZATION NAME(S) AND ADDRESS(ES)

U.S. Army Engineer Waterways Experiment Station

Environmental Laboratory

3909 Halls Ferry Road, Vicksburg, MS 39180-6199;

School of Human Performance and Recreation

University of Southem Mississinni. Hattiesburg. MS 39406-5142

9. SPONSORING / MONITORING AGENCY NAME(S) AND ADDRESS(ES)

U. S. Department of Defense

Office of the Deputy Assistant Secretary of Defense for the Environment

Washington, DC 22202

\section{SUPPLEMENTARY NOTES}

Available from National Technical Information Service, 5285 Port Royal Road, Springfield, VA 22161.

12a. DISTRIBUTION / AVAILABILITY STATEMENT

12b. DISTRIBUTION CODE

Approved for public release; distribution is unlimited.

13. ABSTRACT (Maximum 200 words)

This report summarizes the conclusions and recommendations resulting from 1991-92 work in the Department of Defense (DoD), Legacy Resource Management Program's Education, Public Awareness, and Recreation Task Area. Following a discussion of the Task Area objectives and methods, conclusions and recommendations are presented that cover both natural and cultural resources. Several natural resources issues are examined, including authority and access, resources and activities, mandated access, Native American access, public awareness, legal liabilities, and non-DoD Federal management policies. For cultural resources, the emphasis is on Native American access to sacred and religious sites on DoD lands.

\begin{tabular}{|c|c|c|c|c|}
\hline \multirow{2}{*}{\multicolumn{2}{|c|}{$\begin{array}{l}\text { 14. SUBJECT TERMS } \\
\text { Access } \\
\text { Cultural resources management } \\
\text { Department of Defense }\end{array}$}} & \multirow{2}{*}{\multicolumn{2}{|c|}{$\begin{array}{l}\text { Natural resources management } \\
\text { Recreation }\end{array}$}} & $\begin{array}{l}\text { 15. NUMBER OF PAGES } \\
32\end{array}$ \\
\hline & & & & 16. PRICE CODE \\
\hline $\begin{array}{l}\text { 17. SECURITY CLASSIFICATION } \\
\text { OF REPORT } \\
\text { UNCLASSIFIED }\end{array}$ & & $\begin{array}{l}\text { SECURITY CLASSIFICATION } \\
\text { OF THIS PAGE } \\
\text { UNCLASSIFIED }\end{array}$ & $\begin{array}{l}\text { 19. SECURITY CLASSIFICATION } \\
\text { OF ABSTRACT }\end{array}$ & 20. LIMITATION OF ABSTRACT \\
\hline
\end{tabular}




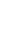

